\title{
Maternal bleeding complications in pregnancies affected by red blood cell alloimmunization
}

\section{Klara Beitl}

Medical University Vienna

Iris Holzer ( $\square$ iris.holzer@meduniwien.ac.at )

Medical University Vienna https://orcid.org/0000-0003-1739-7545

Günther F. Körmöczi

Medical University Vienna

Antonia Valentina Hein

https://orcid.org/0000-0002-9552-0468

Judit Föster

Medical University Vienna https://orcid.org/0000-0001-6371-122X

Rudolf Seemann

Medical University Vienna

Johannes Ott

Medical University Vienna

Barbara Ulm

Medical University Vienna

\section{Research Article}

Keywords: Red blood cell alloimmunization, Maternal hemorrhage, Bleeding complication, Postpartum bleeding

Posted Date: September 3rd, 2021

DOI: https://doi.org/10.21203/rs.3.rs-619088/v1

License: (c) (i) This work is licensed under a Creative Commons Attribution 4.0 International License. Read Full License

Version of Record: A version of this preprint was published at European Journal of Obstetrics \&amp; Gynecology and Reproductive Biology on March 1st, 2022. See the published version at https://doi.org/10.1016/j.ejogrb.2022.02.178. 


\section{Abstract \\ Purpose}

To investigate whether women with red blood cell (RBC) alloimmunization are more likely to experience bleeding complications during pregnancy or delivery than women without RBC alloimmunization.

\section{Methods}

Retrospective study involving all singleton pregnancies affected by RBC alloimmunization and without pre-existing maternal bleeding disorders or placenta previa, from 1 July 1999 to 30 June 2019 ("cases"). Only bleedings not related to invasive procedures (amnio- or cordocenteses) were included. Cases were compared to controls without RBC alloimmunization, matched for maternal age and body mass index, from the same tertiary referral center in Austria.

\section{Results}

130 cases were compared to 130 controls. Cases had significantly more previous pregnancies and miscarriages and their newborns had lower birthweight and were more often transferred to the intensive care unit than newborns of controls. $18 / 130(13.8 \%)$ cases, compared to $8 / 130(6.2 \%)$ controls experienced any bleeding during pregnancy or delivery $(p=0.061)$. Bleeding most often happened during the third trimester (cases: $4.6 \%$ vs. controls $0.8 \%, p=0.12$ ) and during or after delivery (cases: $7.7 \%$ vs. controls: $4.6 \%, p=0.168$ ). Binary logistic regression for the prediction of any bleeding complication during pregnancy, delivery or postpartum revealed immunization against RBC antigens as the only independent contributor $(p=0.04)$. Age, smoking, or previous obstetric history had no influence on the likelihood of maternal bleeding complications. Neither RBC antibody specificity nor titers were predictive of maternal bleeding during pregnancy or delivery.

\section{Conclusion}

Pregnancies affected by RBC alloimmunization are at increased risk of maternal bleeding complications during pregnancy and delivery.

\section{Introduction}

Maternal alloimmunization to fetal red blood cell (RBC) antigens, mostly concerning D, followed by $\mathrm{K}, \mathrm{c}$, and $\mathrm{E}$, may result in severe fetal and neonatal anemia, and eventually hydrops and death, during pregnancy or delivery [1]. The incidence of RBC alloimmunization in pregnant women range from 0.4$2.7 \%$ [2]. The risk could be reduced by routine use of Rh $\mathrm{D}$ immunoglobulin postpartum from $16-2 \%$ and by routine antenatal prophylaxis further to $0.3 \%[3,4]$. 
As a result of the implementation of routinely performed early alloantibody screening, the use of accurate guidelines and the specification of tertiary referral centers for fetal therapy, severe fetal alloimmune hydrops with potentially lethal outcome a few decades ago has almost disappeared [5-7]. Still, the survival of fetuses with severe hydrops is significantly lower than that of anemic fetuses without hydrops. In 1981, the intravascular intrauterine transfusion (IUT) has been introduced which is considered a safe procedure that significantly improves the perinatal outcome in fetuses with severe anemia [8]. The procedure-related fetal loss rate of IUTs is approximately $2 \%$, with higher loss rates at lower gestational ages [9-11].

Fetal and neonatal outcomes in RBC alloimmunization have substantially improved, but data on maternal complications in these pregnancies are scarce. In the majority of pregnancies with RBC alloimmunization, the origin of maternal sensitization is not clear, and most antigen-negative women with antigen-positive partners do not develop potentially harmful antibodies (AB), while others develop specific $A B$ that remain at low levels throughout gestation. Pre- and perinatal hemorrhage may cause alloimmunization, or boostering of maternal $A B$ production in sensitized pregnancies [1]. $A$ "predisposition" to bleeding complications might explain why some women develop clinically significant RBC alloimmunization while others don't. These bleedings would not necessarily cause relevant vaginal hemorrhage but could explain alloimmunization, hypothetically through transplacental micro-hemorrhage during gestation or increased feto-maternal transfusion during birth and placental abruption.

The aim of this study was to evaluate the prevalence of bleeding complications in women alloimmunized to fetal $R B C$ antigens at $A B$ titers sufficient to potentially affect the fetus and newborn, compared to women without these $A B$, during pregnancy and delivery. We hypothesized that $R B C$ alloimmunized women were more likely to suffer from bleeding complications during pregnancy and postpartum compared to women without RBC AB.

\section{Materials And Methods}

In this retrospective cohort study, we included women who presented to the Department of Obstetrics and Gynecology at a tertiary referral center for RBC alloimmunization between July 1, 1999 and June 30, 2019.

We included all consecutive patients with viable pregnancies (at or above $12+0$ gestational weeks, as confirmed by first trimester screening ultrasound) and with RBC $A B$ and an $A B$ titer $>=16$ for anti-D and other non-D $A B$, or $>=4$ for anti-Kell, respectively [12-14]. Exclusion criteria comprised $A B$ titers below these specific thresholds; other $A B$ not possibly affecting the offspring; non-invasive maternal blood testing results indicating an antigen negative fetus; birth of an antigen-negative child; and unknown pregnancy outcome, multiple pregnancies, and maternal age $<18$ years. Furthermore, we excluded patients with pre-existing bleeding disorders (thalassemia, thrombophilia, factor V Leiden, protein $\mathrm{S}$ deficiency) and women with antithrombotic therapy or placenta previa. This resulted in a final study cohort of 130 pregnancies with RBC alloimmunization (Flowchart Fig. 1). Patients with RBC AB were 
managed according to current guidelines [1], with ultrasound and Doppler assessment every 1-4 weeks, depending of the $A B$ specificity and titer, gestational age, and history of previous affected pregnancies. When Doppler in the middle cerebral artery indicated fetal anemia or in the presence of fetal hydrops, cordocentesis and intrauterine transfusions were performed, according to standard protocols [1]. Delivery was planned at 36-37 week's gestation, after a last intrauterine transfusion, if required, at 34 weeks' gestation, for patients with RBC alloimmunization ("cases").

For group comparison, a control group of 130 pregnant women without RBC AB over the same 20-year period was randomly selected by matching cases to controls $1: 1$ applying matching criteria maternal age at presentation and pre-pregnancy body mass index ("controls").

The study protocol complies with the declaration of Helsinki and was approved by the Institutional Review Board of the Medical University of Vienna (institutional review board number 2217/2019). In retrospective studies neither written nor verbal informed consent is necessary according to the Ethics Committee of the Medical University of Vienna.

\section{Parameters Analyzed}

The primary endpoint of this investigation was the occurrence of any bleeding complications during pregnancy and delivery among cases (women with RBC $A B$ ) and matched controls (women without RBC $\mathrm{AB}$ ) and the comparison between groups.

Bleeding that occurred in the setting of early abortion was not counted. Thus, only women who reached a gestational age $\geq 12+0$ weeks were included. Bleeding that occurred within one week of an invasive procedure such as amniocentesis, cordocentesis, or IUT, was presumed to be causally related and thus consequently not counted.

The following basic patient characteristics were collected: maternal age at first visit, body mass index (BMI), gravidity, parity, previous miscarriage and cesarean section, smoking during pregnancy and gestational age at first visit. We also assessed the occurrence of preterm premature rupture of membranes, stillbirth, gestational age at delivery, neonatal birth weight and transfer to neonatal intensive care unit (NICU). Data were acquired retrospectively using AKIM® software (SAP Software Solutions Austria, Vienna, Austria) and PIA Fetal Database software (GE-Viewpoint, Wessling, Germany), which is used as the basic perinatological database in our department.

In addition to maternal and fetal outcome parameters, $A B$ titer at initial presentation, maximum $A B$ titers, and gestational age at maximum titers were collected. The following maternal RBC AB antibodies resulted from our data research and were therefore enrolled: anti-D, anti-K, anti-C, anti-E, anti-M, anti-S, and anti-Fya. All AB specificities and titers were determined at the Department of Blood Group Serology and Transfusion Medicine, General Hospital of Vienna, Vienna, Austria according to ISO 9001 and ISO 15189 quality standards. 
Routine blood group antigen typing was carried out by gel centrifugation technique using polyclonal or monoclonal Bio-Rad (Cressier, Switzerland) reagents and equipment, as described previously [15]. AntiRBC antibody screening and identification was performed by IAT in gel matrix (Bio-Rad). Antibody titration was performed in tube technique with polyspecific anti-human globulin (Ortho Clinical Diagnostics, Neckargemünd, Germany).

\section{Statistical Analysis}

Continuous data are shown as mean \pm standard deviation or median (minimum, maximum) and compared using Mann Whitney U-Test. Categorical parameters are presented as counts and percentages and analyzed using Chi-square test or Fisher's exact test. Univariable binary regression models were used to assess the predictive potential of immunization on any bleeding events. For these regression models, odds ratios $(\mathrm{OR})$ with $95 \%$ confidence intervals $(95 \% \mathrm{Cl})$ and the corresponding $p$-values are provided. Statistical significance was defined by two-sided $P$-values $<0.05$. Statistical analyses were performed using SPSS 24.0 (IBM SPSS, USA).

\section{Results}

One-hundred-and-thirty women with RBC alloimmunization and 130 controls without RBC AB were included in the analysis. One-hundred-and-two women had anti-D AB (102/130, 78.5\%), nine anti-E (6.9\%), eight anti-c (6.2\%), and seven anti-Kell (5.4\%). Four women (3.1\%) had other RBC AB (Table 1). The median RBC AB titer at the initial visit at our center was 64 (min-max: 0-4000), the median maximum $A B$ titer encountered was 256 (min-max: 4-160000) at a median gestational age (GA) of 30.0 weeks (IQR: 23.8-33.0 weeks). Patient characteristics of cases and controls are summarized in Table 2. Women with RBC alloimmunization had significantly more previous pregnancies and deliveries than controls $(p<$ $0.001)$, and they were significantly more likely to have had a previous miscarriage $(p=0.023)$.

Table 1

Antibody distribution among

130 women with $R B C$

alloimmunization

\begin{tabular}{|lll|}
\hline Antibody type & $\mathbf{N}$ & $\%$ \\
\hline anti-D & 102 & 78.5 \\
anti-E & 9 & 6.9 \\
anti-K & 7 & 5.4 \\
anti-C & 8 & 6.2 \\
anti-M & 1 & 0.8 \\
anti-S & 1 & 0.8 \\
anti-Fya & 2 & 1.5 \\
\hline
\end{tabular}

Page 5/19 
Table 2

Patient characteristics for women with ("immunized") and without red cell alloantibodies ("nonimmunized")

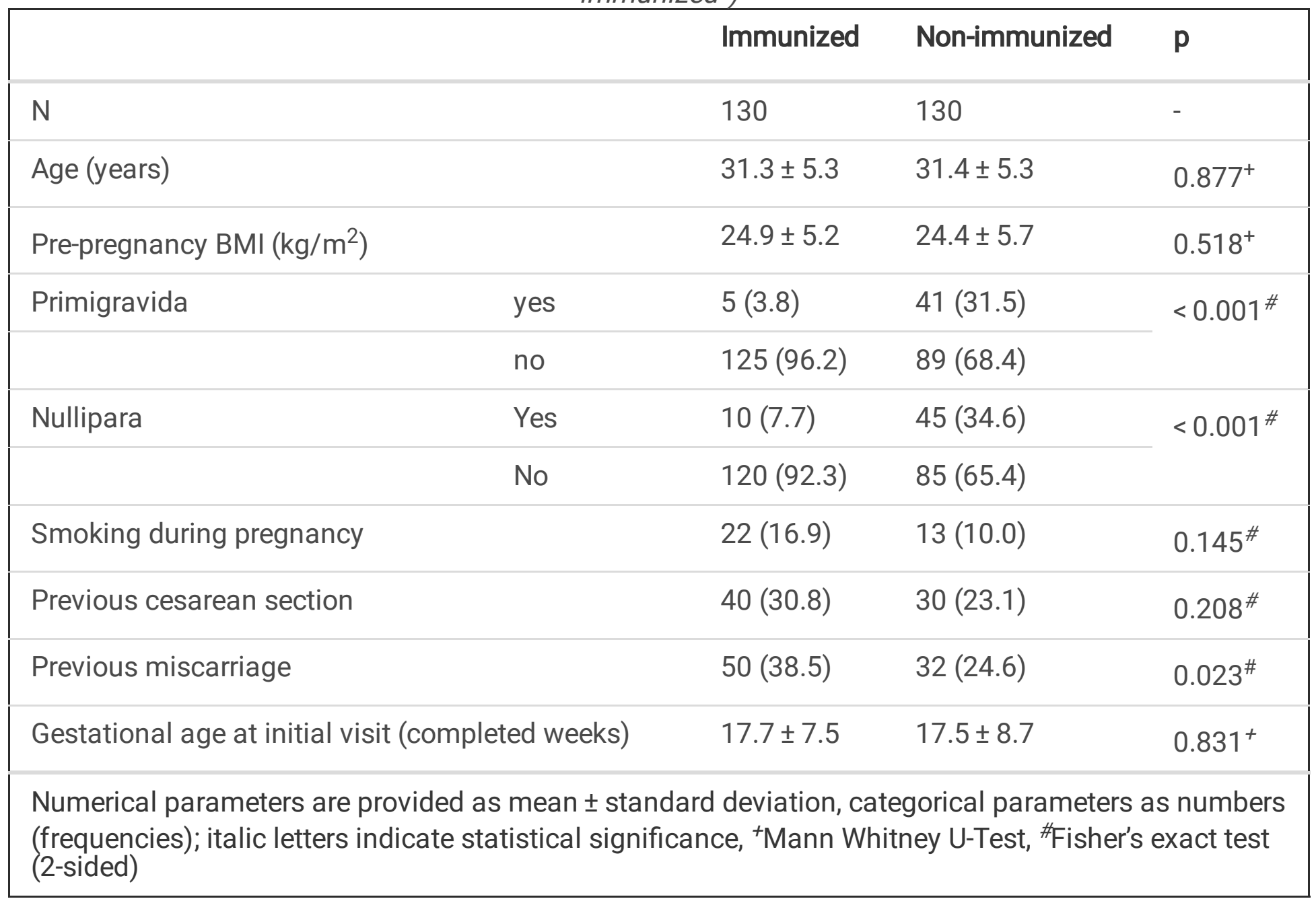

Women with RBC alloimmunization tended to have more overall bleeding complications during pregnancy and delivery, compared to controls $(p=0.061$, Table 3$)$. The rates of hemorrhage during the first $(2.3 \%$ among cases vs. $1.5 \%$ among controls; $p=1)$ and second $(0 \%$ vs. $1.5 \% ; p=0.498)$ trimesters did not differ between groups. Third trimester bleeding complications were slightly more common in women with RBC alloimmunization $(4.6 \%)$ than in controls $(0.8 \% ; p=0.12)$. Intra- and postpartum bleeding was again slightly more common among RBC alloimmunized women (7.7\%) than among controls $(4.6 \% ; p=0.168)$. Details of maternal bleeding complications are provided in Table 4. Details of outcomes are listed in Suppl. Table 1. 
Table 3

Bleeding complications during pregnancy and delivery, and outcome for women with ("immunized") and without red cell alloantibodies ("non-immunized")

\begin{tabular}{|llll|}
\hline & Immunized & Non-immunized & $\mathbf{p}^{\#}$ \\
\hline $\mathrm{N}$ & 130 & 130 & - \\
\hline Any bleeding & $18(13.8)$ & $8(6.2)$ & 0.061 \\
\hline Any bleeding during pregnancy & $9(6.9)$ & $5(3.8)$ & 0.410 \\
\hline 1st trimester bleeding & $3(2.3)$ & $2(1.5)$ & 1.000 \\
\hline 2nd trimester bleeding & 0 & $2(1.5)$ & 0.498 \\
\hline 3rd trimester bleeding & $6(4.6)$ & $1(0.8)$ & 0.120 \\
\hline Intra- and postpartum bleeding & $10(7.7)$ & $4(4.6)$ & 0.168 \\
\hline Categorical parameters are provided as numbers (frequencies); \#Fisher's exact test (2-sided) \\
\hline
\end{tabular}


Table 4

Details of maternal bleeding complications

\begin{tabular}{|c|c|c|c|c|c|c|}
\hline Nr. & $\mathrm{AB}$ & $\begin{array}{l}\text { Gestational age } \\
\text { at time of } \\
\text { bleeding (weeks } \\
\text { + days) }\end{array}$ & Bleeding details & $\begin{array}{l}\text { Estimated } \\
\text { blood } \\
\text { loss }\end{array}$ & $\begin{array}{l}\text { Hb level } \\
\text { before } \\
\text { bleeding }\end{array}$ & $\begin{array}{l}\text { Hb level } \\
\text { after } \\
\text { bleeding }\end{array}$ \\
\hline \multicolumn{7}{|c|}{ Immunized } \\
\hline 1 & $\begin{array}{l}\text { anti- } \\
\mathrm{c}\end{array}$ & $10+0$ & $\begin{array}{l}\text { vaginal bleeding of unknown } \\
\text { origin }\end{array}$ & $\mathrm{n} / \mathrm{a}$ & $\mathrm{n} / \mathrm{a}$ & 13.1 \\
\hline 2 & $\begin{array}{l}\text { anti- } \\
D\end{array}$ & $12+2$ & $\begin{array}{l}\text { vaginal bleeding of unknown } \\
\text { origin }\end{array}$ & $\mathrm{n} / \mathrm{a}$ & $\mathrm{n} / \mathrm{a}$ & 14.3 \\
\hline 3 & $\begin{array}{l}\text { anti- } \\
\text { D }\end{array}$ & $13+1$ & $\begin{array}{l}\text { vaginal spotting of unknown } \\
\text { origin, no hospital admission }\end{array}$ & $\mathrm{n} / \mathrm{a}$ & 12.8 & 12.5 \\
\hline 4 & $\begin{array}{l}\text { anti- } \\
\text { D }\end{array}$ & $25+5$ & PROM and preterm labor & $\mathrm{n} / \mathrm{a}$ & 11.2 & 10.0 \\
\hline 5 & $\begin{array}{l}\text { anti- } \\
D \\
\text { anti- } \\
C\end{array}$ & $31+3$ & $\begin{array}{l}\text { severe intrapartum } \\
\text { hemorrhage during c.s., } \\
\text { preterm PROM, abruption of } \\
\text { placenta }\end{array}$ & $>500 \mathrm{~mL}$ & 10 & 9.1 \\
\hline 6 & $\begin{array}{l}\text { anti- } \\
\text { D }\end{array}$ & $33 .+0$ & $\begin{array}{l}\text { unknown origin, no hospital } \\
\text { admission }\end{array}$ & $\mathrm{n} / \mathrm{a}$ & $\mathrm{n} / \mathrm{a}$ & $\mathrm{n} / \mathrm{a}$ \\
\hline 7 & $\begin{array}{l}\text { anti- } \\
\text { D }\end{array}$ & $33+3$ & $\begin{array}{l}\text { unknown origin, no hospital } \\
\text { admission }\end{array}$ & $\mathrm{n} / \mathrm{a}$ & $\mathrm{n} / \mathrm{a}$ & $\mathrm{n} / \mathrm{a}$ \\
\hline 8 & $\begin{array}{l}\text { anti- } \\
D\end{array}$ & $34+2$ & PPH, c.s. & $2000 \mathrm{~mL}$ & 11.5 & 8.6 \\
\hline 9 & $\begin{array}{l}\text { anti- } \\
\text { D }\end{array}$ & $34+6$ & PPH, c.s. & $>1000 \mathrm{~mL}$ & 11.9 & 11.2 \\
\hline 10 & $\begin{array}{l}\text { anti- } \\
\text { D }\end{array}$ & $36+0$ & PPH, vaginal delivery & $>500 \mathrm{~mL}$ & $\mathrm{n} / \mathrm{a}$ & 12.6 \\
\hline 11 & $\begin{array}{l}\text { anti- } \\
D \\
\text { anti- } \\
C\end{array}$ & $37+1$ & PPH, c.s. & $>1000 \mathrm{~mL}$ & 8.2 & 6.9 \\
\hline 12 & $\begin{array}{l}\text { anti- } \\
\text { D }\end{array}$ & $37+5$ & PPH, c.s. & $>1000 \mathrm{~mL}$ & 9.7 & 8.6 \\
\hline
\end{tabular}

$\mathrm{n} / \mathrm{a}$, not applicable; $\mathrm{AB}$, antibodies; $\mathrm{Hb}$, hemoglobin; PROM, premature rupture of membranes; c.s., cesarean section;

PPH postpartum hemorrhage; RBC, red blood cells 


\begin{tabular}{|c|c|c|c|c|c|c|}
\hline Nr. & $A B$ & $\begin{array}{l}\text { Gestational age } \\
\text { at time of } \\
\text { bleeding (weeks } \\
+ \text { days) }\end{array}$ & Bleeding details & $\begin{array}{l}\text { Estimated } \\
\text { blood } \\
\text { loss }\end{array}$ & $\begin{array}{l}\text { Hb level } \\
\text { before } \\
\text { bleeding }\end{array}$ & $\begin{array}{l}\text { Hb level } \\
\text { after } \\
\text { bleeding }\end{array}$ \\
\hline 13 & $\begin{array}{l}\text { anti- } \\
D \\
\text { anti- } \\
C\end{array}$ & $37+6$ & $\mathrm{PPH}$, vaginal delivery & $>500 \mathrm{~mL}$ & 12.7 & 10.7 \\
\hline 14 & $\begin{array}{l}\text { anti- } \\
\text { D }\end{array}$ & $37+6$ & $\begin{array}{l}\text { Placental abruption } \\
\text { bleeding, intrauterine fetal } \\
\text { death }\end{array}$ & $700 \mathrm{~mL}$ & 10.8 & 10.3 \\
\hline 15 & $\begin{array}{l}\text { anti- } \\
\text { D }\end{array}$ & $38+3$ & $\mathrm{PPH}$, vaginal delivery & $>1000 \mathrm{ml}$ & 10.8 & 11.2 \\
\hline 16 & $\begin{array}{l}\text { anti- } \\
\text { D }\end{array}$ & $38+6$ & vaginal bleeding, PROM & $\mathrm{n} / \mathrm{a}$ & 12.6 & 12.4 \\
\hline 17 & $\begin{array}{l}\text { anti- } \\
\mathrm{K}\end{array}$ & $39+2$ & $\begin{array}{l}\mathrm{PPH}, \text { vaginal delivery, uterine } \\
\text { atony and placental } \\
\text { retention, } 4 \text { RBC } \\
\text { transfusions }\end{array}$ & $>500 \mathrm{~mL}$ & 12.5 & 6.8 \\
\hline 18 & $\begin{array}{l}\text { anti- } \\
\text { D }\end{array}$ & $39+5$ & unknown origin & $\mathrm{n} / \mathrm{a}$ & $\mathrm{n} / \mathrm{a}$ & 11.6 \\
\hline 19 & $\begin{array}{l}\text { anti- } \\
\text { D }\end{array}$ & $40+0$ & Placental abruption & $\mathrm{n} / \mathrm{a}$ & 9.4 & 8.1 \\
\hline \multicolumn{7}{|c|}{ Non-immunized } \\
\hline 1 & 0 & first trimester & $\begin{array}{l}\text { vaginal bleeding of unknown } \\
\text { origin, inpatient stay at } \\
\text { external hospital }\end{array}$ & $\mathrm{n} / \mathrm{a}$ & $\mathrm{n} / \mathrm{a}$ & $\mathrm{n} / \mathrm{a}$ \\
\hline 2 & 0 & first trimester & $\begin{array}{l}\text { vaginal spotting of unknown } \\
\text { origin, no hospital admission }\end{array}$ & $\mathrm{n} / \mathrm{a}$ & $\mathrm{n} / \mathrm{a}$ & $\mathrm{n} / \mathrm{a}$ \\
\hline 3 & 0 & $15+0$ & $\begin{array}{l}\text { vaginal spotting of unknown } \\
\text { origin, no hospital admission }\end{array}$ & $\mathrm{n} / \mathrm{a}$ & $\mathrm{n} / \mathrm{a}$ & $\mathrm{n} / \mathrm{a}$ \\
\hline 4 & 0 & $22+2$ & vaginal bleeding, infection & $\mathrm{n} / \mathrm{a}$ & 10.6 & 10.3 \\
\hline 5 & 0 & $28+0$ & $\begin{array}{l}\text { vaginal bleeding, infection, } \\
\text { PROM }\end{array}$ & $\mathrm{n} / \mathrm{a}$ & 13.4 & 13.1 \\
\hline 6 & 0 & $34+0$ & $\begin{array}{l}\text { PPH, after vaginal delivery, } \\
\text { placental retention }\end{array}$ & $>1000 \mathrm{~mL}$ & 11.0 & 8.0 \\
\hline 7 & 0 & $38+1$ & PPH, c.s. & $>1000 \mathrm{~mL}$ & 13.6 & 9.8 \\
\hline
\end{tabular}

n/a,not applicable; $A B$, antibodies; $\mathrm{Hb}$, hemoglobin; PROM, premature rupture of membranes; c.s., cesarean section;

PPH postpartum hemorrhage; RBC, red blood cells 


\begin{tabular}{|c|c|c|c|c|c|c|}
\hline Nr. & $A B$ & $\begin{array}{l}\text { Gestational age } \\
\text { at time of } \\
\text { bleeding (weeks } \\
\text { + days) }\end{array}$ & Bleeding details & $\begin{array}{l}\text { Estimated } \\
\text { blood } \\
\text { loss }\end{array}$ & $\begin{array}{l}\text { Hb level } \\
\text { before } \\
\text { bleeding }\end{array}$ & $\begin{array}{l}\mathrm{Hb} \text { level } \\
\text { after } \\
\text { bleeding }\end{array}$ \\
\hline 8 & 0 & $39+2$ & $\begin{array}{l}\text { PPH, vaginal delivery and } \\
\text { cervical tear }\end{array}$ & $800 \mathrm{~mL}$ & 11.7 & 10.2 \\
\hline 9 & 0 & $41+5$ & PPH, c.s., uterine atony & $>1000 \mathrm{~mL}$ & 8.5 & 7.5 \\
\hline \multicolumn{7}{|c|}{$\begin{array}{l}\text { n/a,not applicable; } A B \text {, antibodies; Hb, hemoglobin; PROM, premature rupture of membranes; c.s., } \\
\text { cesarean section; }\end{array}$} \\
\hline \multicolumn{7}{|c|}{ PPH postpartum hemorrhage; $R B C$, red blood cells } \\
\hline
\end{tabular}

In binary logistic regression, RBC alloimmunization and maternal bleeding complications during pregnancy and delivery were strongly associated $(\mathrm{OR}=2.451 ; 95 \% \mathrm{Cl} 1.025-5.858)$. No association was found between maternal bleeding complications and maternal age, body mass index, gravidity, parity, smoking status, or previous cesarean section and miscarriage (Table 5). Neither the AB specificity (anti-D, anti-Kell, or other $A B$ ) nor $A B$ titers were associated with maternal bleeding complications (Table 6). 
Table 5

Binary logistic regression model for the prediction of any bleeding complications during pregnancy or delivery

\begin{tabular}{|c|c|c|c|c|c|}
\hline & & Any bleeding & No bleeding & OR & $p$ \\
\hline \multicolumn{2}{|l|}{$\mathrm{N}$} & 26 & 234 & - & - \\
\hline \multicolumn{2}{|c|}{ Age (years) } & $30.7 \pm 5.1$ & $31.4 \pm 24.6$ & $0.976(0.903 ; 1.054)$ & 0.537 \\
\hline \multicolumn{2}{|c|}{ Pre-pregnancy BMI $\left(\mathrm{kg} / \mathrm{m}^{2}\right)$} & $24.9 \pm 7.2$ & $24.6 \pm 5.3$ & $1.010(0.922 ; 1.105)$ & 0.837 \\
\hline \multirow[t]{3}{*}{ Gravidity } & 1 & $1(3.8)$ & $45(19.2)$ & ref & \multirow[t]{3}{*}{0.203} \\
\hline & 2 & $10(38.5)$ & $67(28.6)$ & $6.716(0.831 ; 54.304)$ & \\
\hline & $\geq 3$ & $15(57.7)$ & $122(52.1)$ & $5.533(0.710 ; 43.103)$ & \\
\hline \multirow[t]{3}{*}{ Parity } & 0 & $2(7.7)$ & $53(22.6)$ & ref & \multirow[t]{3}{*}{0.238} \\
\hline & 1 & $12(46.2)$ & $85(36.3)$ & $3.741(0.805 ; 17.377)$ & \\
\hline & $\geq 2$ & $12(46.2)$ & $96(41.0)$ & $3.312(0.714 ; 15.360)$ & \\
\hline \multicolumn{2}{|c|}{ Smoking during pregnancy } & $1(3.8)$ & $34(14.5)$ & $0.235(0.031 ; 1.794)$ & 0.136 \\
\hline \multicolumn{2}{|c|}{ Previous Cesarean Section } & $6(23.1)$ & $64(27.4)$ & $0.797(0.306 ; 2.074)$ & 0.642 \\
\hline \multicolumn{2}{|c|}{ Previous miscarriage } & $10(38.5)$ & $72(30.8)$ & $1.406(0.609 ; 3.249)$ & 0.425 \\
\hline \multicolumn{2}{|c|}{ Immunization } & $18(69.2)$ & $112(47.9)$ & $2.451(1.025 ; 5.858)$ & 0.044 \\
\hline \multicolumn{6}{|c|}{$\begin{array}{l}\text { Numerical parameters are provided as mean } \pm \text { standard deviation, categorical parameters as numbers } \\
\text { (frequencies); italic letters indicate statistical significance }\end{array}$} \\
\hline \multicolumn{6}{|c|}{ ref, reference } \\
\hline
\end{tabular}


Table 6

Binary logistic regression model for the prediction of any bleeding complications in immunized patients during pregnancy or delivery

\begin{tabular}{|c|c|c|c|c|}
\hline & Any bleeding & No bleeding & OR & $\mathbf{p}$ \\
\hline Antibody anti-D & $15(83.3)$ & $87(77.7)$ & ref & 0.824 \\
\hline anti-K & $1(5.6)$ & $6(5.4)$ & $0.967(0.109 ; 8.610)$ & 0.976 \\
\hline others & $2(11.1)$ & $19(17.0)$ & $0.611(0.129 ; 2.896)$ & 0.534 \\
\hline Titer level at initial visit & $64(0-1024)$ & $64(0-4000)$ & $0.999(0.997-1.001)$ & 0.406 \\
\hline Maximum titer & $256(4-16000)$ & $256(8-16000)$ & $1(1-1)$ & 0.688 \\
\hline \multicolumn{5}{|c|}{$\begin{array}{l}\text { Numerical parameters are provided as median (min-max), categorical parameters as numbers } \\
\text { (frequencies) }\end{array}$} \\
\hline \multicolumn{5}{|l|}{ ref, reference } \\
\hline \multicolumn{5}{|c|}{$\begin{array}{l}\text { *Maternal age }<18 \text { years; RBC antibody titers below the threshold; Other antibodies not possibly } \\
\text { affecting the offspring; Non-invasive maternal blood testing results indicating an antigen negative } \\
\text { fetus; Birth of an antigen-negative child; Unknown pregnancy outcome; Multiple pregnancies; Placenta } \\
\text { previa; Maternal pre-existing bleeding disorders: thalassemia, thrombophilia, factor V Leiden, protein S } \\
\text { deficiency; Current antithrombotic therapy }\end{array}$} \\
\hline
\end{tabular}

\section{Discussion}

We investigated the prevalence of maternal bleeding complications during pregnancy and delivery in women with RBC alloimmunization, compared to controls without RBC alloantibodies. Women with RBC alloimmunization had a higher overall prevalence of bleeding complications than controls. Higher rates of maternal hemorrhage in RBC alloimmunized cases, compared to controls, were independent of maternal age or previous obstetric history. Of note, bleedings that occurred within one week after an invasive procedure, such as amniocentesis or cordocentesis, were not counted for this study.

While the fetal risks and outcomes in RBC alloimmunization are well known [16], maternal complications in RBC alloimmunized women have not been studied so far. To the best of our knowledge, this investigation is the first to provide data on maternal bleeding complications in RBC alloimmunized women during pregnancy and delivery.

Despite substantial improvements in fetal medicine when implementing management according to Doppler assessment of middle cerebral artery as the threshold for fetal intervention [17] and gaining experience in IUTs over the last decades, adverse fetal or neonatal outcomes still exist. A large review of IUTs over 20 years in Sweden demonstrated a procedure-related complication rate of $4.9 \%$, predominantly associated with technical difficulties in placing the needle into the right position. Ten patients from this 
review were delivered by emergency cesarean section resulting in live born children, but four mothers lost their children in conjunction with the IUTs [17]. Other studies report a fetal loss rate between 0.9 and $4.9 \%$ [18]. Fetal distress during or after the procedure is the most serious complication that may result in emergency delivery with the risk of prematurity, neonatal asphyxia or even infant death [18]. Procedurerelated risks are increased when invasive, in utero transfusion is instituted prior to gestational weeks 22 to treat severe early-onset fetal anemia [19]. Data on the long-term outcome of children after antenatal transfusion demonstrated a normal neurodevelopmental outcome in more than $95 \%$, with the highest risk for neurodevelopmental impairment in the presence of fetal hydrops [20]. In our study cohort, no severe complications after invasive procedures such as cordocentesis or IUT occurred. Thus, no additional patients had to be excluded due to procedure- related complications.

Even simple prenatal invasive procedures and every fetal intervention carry a specific risk of any kind of complications, typically bleeding or infection, to the mother, while not providing any direct medical benefits to the mother herself [21]. A recent review on maternal complications following open and fetoscopic fetal surgeries demonstrated a maternal complication rate of $6.2 \%$ for fetoscopic and $20.9 \%$ for open fetal surgeries [21]. The rate of serious maternal complications was $1.7 \%$ in fetoscopic and $4.5 \%$ in open procedures and included severe infection, sepsis, lung edema, complete heart block, hemorrhage, placental abruption, maternal cardiac arrest, uterine rupture and caesarean hysterectomy [21]. A retrospective investigation on 187 pregnancies after fetal surgery revealed a prevalence of premature, preterm rupture of membranes of $44.4 \%$, chorio-amniotic membrane separation in $36 \%$, chorioamnionitis in $4.5 \%$, vaginal bleeding in $6.7 \%$ and placental abruption in $6.2 \%$ of patients [22]. Maternal complications of pregnancies after fetal surgery for spina bifida were chorio-amniotic membrane separation in $15 \%$ and maternal pulmonary embolism, chorioamnionitis, maternal heart block and uterine rupture in $2.1 \%, 1.4 \%$, $0.7 \%$ and $0.7 \%$, respectively [23].

The present study focused on maternal bleeding complications during pregnancy and delivery without considering procedure-related complications of fetal interventions. Our data demonstrate an about doubled rate of any bleeding complications in women with RBC (13.8\%) alloimmunization, compared to women without RBC $A B(6.2 \%)$. For the rarity of the disease, our study cohort was rather large, yet not large enough to allow for a detailed, statistically sound discrimination between groups for bleeding rates, according to the time frames of every single trimester or only for the delivery to postpartum period. While, for example, six women with RBC AB had bleeding complications during the third trimester $(6 / 130,4.6 \%)$, only one women of the control group without RBC AB experienced bleeding during this period (1/130, $0.8 \% ; p=0.12$ ). Based on these proportions, sample size requirements to detect differences in bleeding complications for the third trimester separately, at a power of $80 \%$, calculates the need for 284 women in each group included. Enrollment of such a large patient cohort, even when bleeding complications are not uncommon in the control and in the case groups, is unlikely to be successful for a relatively rare disease such as RBC alloimmunization.

Multiple factors can cause bleeding complications during pregnancy or delivery that can happen in the first, second, and third trimester of pregnancy [24]. Vaginal bleeding in the first trimester is usually defined 
as threatened abortion, eventually related to fetal genetic disorders or implantation difficulties. Bleeding that develops later than the beginning of the second trimester is often idiopathic, and the main risks associated with antepartum hemorrhage of unknown origin are preterm birth and low neonatal birth weight [25-28]. Severe postpartum hemorrhage is among the most common causes of severe, maternal life-threatening complications $[29,30]$. In women with RBC AB, predisposition to ante- or peripartum bleedings may not only be considered a relatively frequent - maternal - pregnancy complication, but hypothetically also the origin of RBC alloimmunization, and boostering of the maternal immune response for subsequent pregnancies.

In a large Korean study, no difference was found between Rh positive and Rh negative primigravida women in terms of adverse pregnancy outcome, e.g. preeclampsia, placenta previa, placental abruption, postpartum hemorrhage and the need for uterine artery embolization [31]. That study, however, did not consider women with RBC AB and only first pregnancies were included. Interestingly, there are studies about a relationship of $A B O$ blood groups and preeclampsia or pregnancy-induced hypertension. Recently published data of a large cohort study of 5.1 million unique persons provide evidence that pregnancyinduced hypertension was less common in blood groups $A$ and $A B$, as compared to blood group 0 [32]. In contrary, other studies suggested that maternal $A$ or $A B$ blood types, but not $B$, were found at increased risk of preeclampsia compared with 0 type women [33] or that blood group 0 was significantly more common in early-onset and less common in late-onset preeclampsia [34]. However, data about the ABO blood groups and bleeding complications in pregnancy are lacking so far.

\section{Study Strengths And Limitations}

A major strength of this study is that it is, to the best of our knowledge, the first to describe maternal bleeding complications in the setting of maternal RBC alloimmunization. All consecutive women with RBC alloimmunization at a single tertiary referral center were eligible. For the analysis, we excluded women with pre-existing bleeding disorders, placenta previa, and cases with hemorrhage related to prenatal invasive procedures. Due to the retrospective study design, complete data sets about the length of hospitalization in case of maternal bleeding, the need for administration of RBC concentrates and hemoglobin values before and after the bleeding were not possible to retrieve. For comparison between groups, we chose to match women without RBC AB from the same center, matched for maternal age and body mass index, and with the same exclusion criteria as for women with RBC AB. Basic patient characteristics for previous obstetric history, namely parity, gravidity, and the rate of previous miscarriages, differed between the two study groups, which is considered a limiting factor of the present investigation. Multivariate regression analysis revealed, however, that these differences in patient characteristics had no significant influence on the risk of maternal bleeding complications.

\section{Conclusion}

Our data demonstrate a higher prevalence of bleeding complications during pregnancy and delivery in women with RBC alloimmunization, compared to women without RBC AB. These bleeding complications 
were not related to antenatal invasive procedures, placenta previa, or pre-existing maternal bleeding disorders. Most bleedings among women with RBC alloimmunization happened during the third trimester or during and after delivery. Maternal age, body mass index, smoking status, and previous obstetric history such as previous miscarriage or cesarean section were not associated with a higher likelihood of maternal bleeding complications. In this study, comparing matched cohorts of 130 women with RBC alloimmunization and 130 women without $\mathrm{RBC} A B$, maternal alloimmunization to RBC antigens was an independent predictor of maternal bleeding complications.

\section{Declarations}

Funding: BU received funding as a Short Time Advisory Board Member of Momenta Pharmaceuticals. The funders had no role in the design and conduct of the study; collection, management, analysis, and interpretation of the data; preparation, review, or approval of the manuscript; and decision to submit the manuscript for publication. All other authors: No funding. Open access funding provided by Medical University of Vienna.

Conflicts of interest/Competing interests: The authors declare no conflict of interest.

Availability of data and material: Available upon request.

Code availability: Not applicable.

Ethics approval: The study complied with the principles outlined in the Helsinki Declaration of 1975, as revised in 2013, and was approved by the institutional review board of the Ethics Committee at the Medical University of Vienna (EK Number 2217/2019).

Consent to participate: In retrospective studies, neither written nor verbal informed consent is required according to the Ethics Committee of the Medical University of Vienna.

Consent for publication :As above.

\section{Authors' contributions:}

KB: Project development, Data analysis, Manuscript writing and editing.

$\mathrm{IH}$ : Data analysis, Manuscript writing and editing.

AVH: Data collection and management, Manuscript editing.

JF: Data collection and management, Manuscript editing.

GK: Data analysis, Manuscript writing and editing.

RS: Data analysis, Manuscript writing and editing. 
JO: Protocol development, Data analysis, Manuscript writing and editing.

BU: Project development, Protocol development, Data analysis, Manuscript writing and editing.

\section{References}

1. (2018) ACOG Practice Bulletin No. 192: Management of Alloimmunization During Pregnancy. Obstet Gynecol 131:e82-e90. doi: 10.1097/AOG.0000000000002528

2. Velkova E (2015) Correlation between the Amount of Anti-D Antibodies and IgG Subclasses with Severity of Haemolytic Disease of Foetus and Newborn. Open Access Maced J Med Sci 3:293-297. doi:10.3889/oamjms.2015.058

3. de Haas M, Finning K, Massey E, Roberts DJ (2014) Anti-D prophylaxis: past, present and future. Transfus Med 24:1-7. doi:10.1111/tme.12099

4. Qureshi H, Massey E, Kirwan D, Davies T, Robson S, White J, Jones J, Allard S, British Society for H (2014) BCSH guideline for the use of anti-D immunoglobulin for the prevention of haemolytic disease of the fetus and newborn. Transfus Med 24:8-20. doi:10.1111/tme.12091

5. Zwiers C, Oepkes D, Lopriore E, Klumper FJ, de Haas M, van Kamp IL (2018) The near disappearance of fetal hydrops in relation to current state-of-the-art management of red cell alloimmunization. Prenat Diagn 38:943-950. doi:10.1002/pd.5355

6. van Kamp IL, Klumper FJ, Bakkum RS, Oepkes D, Meerman RH, Scherjon SA, Kanhai HH (2001) The severity of immune fetal hydrops is predictive of fetal outcome after intrauterine treatment. Am J Obstet Gynecol 185:668-673. doi:10.1067/mob.2001.116690

7. Castleman JS, Kilby MD (2020) Red cell alloimmunization: A 2020 update. Prenat Diagn 40:10991108. doi:10.1002/pd.5674

8. Van Kamp IL, Klumper FJ, Oepkes D, Meerman RH, Scherjon SA, Vandenbussche FP, Kanhai HH (2005) Complications of intrauterine intravascular transfusion for fetal anemia due to maternal redcell alloimmunization. Am J Obstet Gynecol 192:171-177. doi:10.1016/j.ajog.2004.06.063

9. Lindenburg IT, van Kamp IL, van Zwet EW, Middeldorp JM, Klumper FJ, Oepkes D (2013) Increased perinatal loss after intrauterine transfusion for alloimmune anaemia before 20 weeks of gestation. BJOG 120:847-852. doi:10.1111/1471-0528.12063

10. Zwiers C, Lindenburg ITM, Klumper FJ, de Haas M, Oepkes D, Van Kamp IL (2017) Complications of intrauterine intravascular blood transfusion: lessons learned after 1678 procedures. Ultrasound Obstet Gynecol 50:180-186. doi:10.1002/uog.17319

11. Schumacher B, Moise KJ Jr (1996) Fetal transfusion for red blood cell alloimmunization in pregnancy. Obstet Gynecol 88:137-150. doi:10.1016/0029-7844(96)00113-5

12. Cacciatore A, Rapiti S, Carrara S, Cavaliere A, Ermito S, Dinatale A, Imbruglia L, Recupero S, La Galia T, Pappalardo EM, Accardi MC (2009) Obstetric management in Rh alloimmunizated pregnancy. J Prenat Med 3:25-27 
13. Slootweg YM, Lindenburg IT, Koelewijn JM, Van Kamp IL, Oepkes D, De Haas M (2018) Predicting anti-Kell-mediated hemolytic disease of the fetus and newborn: diagnostic accuracy of laboratory management. Am J Obstet Gynecol 219:393 e1-393 e8. doi: 10.1016/j.ajog.2018.07.020

14. Koelewijn JM, Slootweg YM, Folman C, van Kamp IL, Oepkes D, de Haas M (2020) Diagnostic value of laboratory monitoring to predict severe hemolytic disease of the fetus and newborn in non-D and non-K-alloimmunized pregnancies. Transfusion 60:391-399. doi:10.1111/trf.15631

15. Kormoczi GF, Dauber EM, Haas OA, Legler TJ, Clausen FB, Fritsch G, Raderer M, Buchta C, Petzer AL, Schonitzer D, Mayr WR, Gassner C (2007) Mosaicism due to myeloid lineage restricted loss of heterozygosity as cause of spontaneous Rh phenotype splitting. Blood 110:2148-2157. doi:10.1182/blood-2007-01-068106

16. Lieberman L, Callum J, Cohen R, Cserti-Gazdewich C, Ladhani NNN, Buckstein J, Pendergrast J, Lin Y (2020) Impact of red blood cell alloimmunization on fetal and neonatal outcomes: A single center cohort study. Transfusion 60:2537-2546. doi:10.1111/trf.16061

17. Tiblad E, Kublickas M, Ajne G, Bui TH, Ek S, Karlsson A, Wikman A, Westgren M (2011) Procedurerelated complications and perinatal outcome after intrauterine transfusions in red cell alloimmunization in Stockholm. Fetal Diagn Ther 30:266-273. doi:10.1159/000328683

18. Lindenburg IT, van Kamp IL, Oepkes D (2014) Intrauterine blood transfusion: current indications and associated risks. Fetal Diagn Ther 36:263-271. doi:10.1159/000362812

19. Castleman JS, Moise KJ Jr, Kilby MD (2021) Medical therapy to attenuate fetal anaemia in severe maternal red cell alloimmunisation. Br J Haematol 192:425-432. doi:10.1111/bjh.17041

20. Lindenburg IT, Smits-Wintjens VE, van Klink JM, Verduin E, van Kamp IL, Walther FJ, Schonewille H, Doxiadis II, Kanhai HH, van Lith JM, van Zwet EW, Oepkes D, Brand A, Lopriore E and group Ls (2012) Long-term neurodevelopmental outcome after intrauterine transfusion for hemolytic disease of the fetus/newborn: the LOTUS study. Am J Obstet Gynecol 206:141 e1-e8. doi:10.1016/j.ajog.2011.09.024

21. Sacco A, Van der Veeken L, Bagshaw E, Ferguson C, Van Mieghem T, David AL, Deprest J (2019) Maternal complications following open and fetoscopic fetal surgery: A systematic review and metaanalysis. Prenat Diagn 39:251-268. doi:10.1002/pd.5421

22. Golombeck K, Ball RH, Lee H, Farrell JA, Farmer DL, Jacobs VR, Rosen MA, Filly RA, Harrison MR (2006) Maternal morbidity after maternal-fetal surgery. Am J Obstet Gynecol 194:834-839. doi:10.1016/j.ajog.2005.10.807

23. Moehrlen U, Ochsenbein N, Vonzun L, Mazzone L, Horst M, Schauer S, Wille DA, Hagmann C, Kottke R, Grehten P, Casanova B, Strubing N, Moehrlen T, Tharakan S, Padden B, Bassler D, Zimmermann R, Meuli M (2021) Fetal surgery for spina bifida in Zurich: results from 150 cases. Pediatr Surg Int 37:311-316. doi:10.1007/s00383-020-04824-8

24. Towers CV, Burkhart AE (2008) Pregnancy outcome after a primary antenatal hemorrhage between 16 and 24 weeks' gestation. Am J Obstet Gynecol 198:684 e1-5; discussion 684 e5. doi: 10.1016/j.ajog.2008.03.027 
25. Chan CC, To WW (1999) Antepartum hemorrhage of unknown origin-what is its clinical significance? Acta Obstet Gynecol Scand 78:186-190

26. McCormack RA, Doherty DA, Magann EF, Hutchinson M, Newnham JP (2008) Antepartum bleeding of unknown origin in the second half of pregnancy and pregnancy outcomes. BJOG 115:1451-1457. doi:10.1111/j.1471-0528.2008.01856.x

27. Harlev A, Levy A, Zaulan Y, Koifman A, Mazor M, Wiznitzer A, Faizayev E, Sheiner E (2008) Idiopathic bleeding during the second half of pregnancy as a risk factor for adverse perinatal outcome. $J$ Matern Fetal Neonatal Med 21:331-335. doi:10.1080/14767050802038124

28. Koifman A, Levy A, Zaulan Y, Harlev A, Mazor M, Wiznitzer A, Sheiner E (2008) The clinical significance of bleeding during the second trimester of pregnancy. Arch Gynecol Obstet 278:47-51. doi:10.1007/s00404-007-0530-2

29. Geller SE, Koch AR, Garland CE, MacDonald EJ, Storey F, Lawton B (2018) A global view of severe maternal morbidity: moving beyond maternal mortality. Reprod Health 15:98. doi:10.1186/s12978018-0527-2

30. Koblinsky M, Chowdhury ME, Moran A, Ronsmans C (2012) Maternal morbidity and disability and their consequences: neglected agenda in maternal health. J Health Popul Nutr 30:124-130. doi:10.3329/jhpn.v30i2.11294

31. Jin Y, Dong M, Yang SW, Lee KM, Han SW, Seo SH, Lee A, Sohn IS, Kwon HS, Cho GJ, Hwang HS (2020) Evaluation of maternal rhesus blood type as a risk factor in adverse pregnancy outcomes in Korea: a nationwide health insurance database study. Obstet Gynecol Sci 63:448-454. doi:10.5468/ogs.20004

32. Dahlen T, Clements M, Zhao J, Olsson ML, Edgren G (2021) An agnostic study of associations between $\mathrm{ABO}$ and $\mathrm{RhD}$ blood group and phenome-wide disease risk. Elife 10. doi:10.7554/eLife.65658

33. Phaloprakarn C, Tangjitgamol S (2013) Maternal ABO blood group and adverse pregnancy outcomes. J Perinatol 33:107-111. doi:10.1038/jp.2012.73

34. Mahasub N, Boriboonhirunsarn D (2020) Relationship between ABO blood groups and preeclampsia. Hypertens Pregnancy 39:348-353. doi:10.1080/10641955.2020.1777298

\section{Figures}




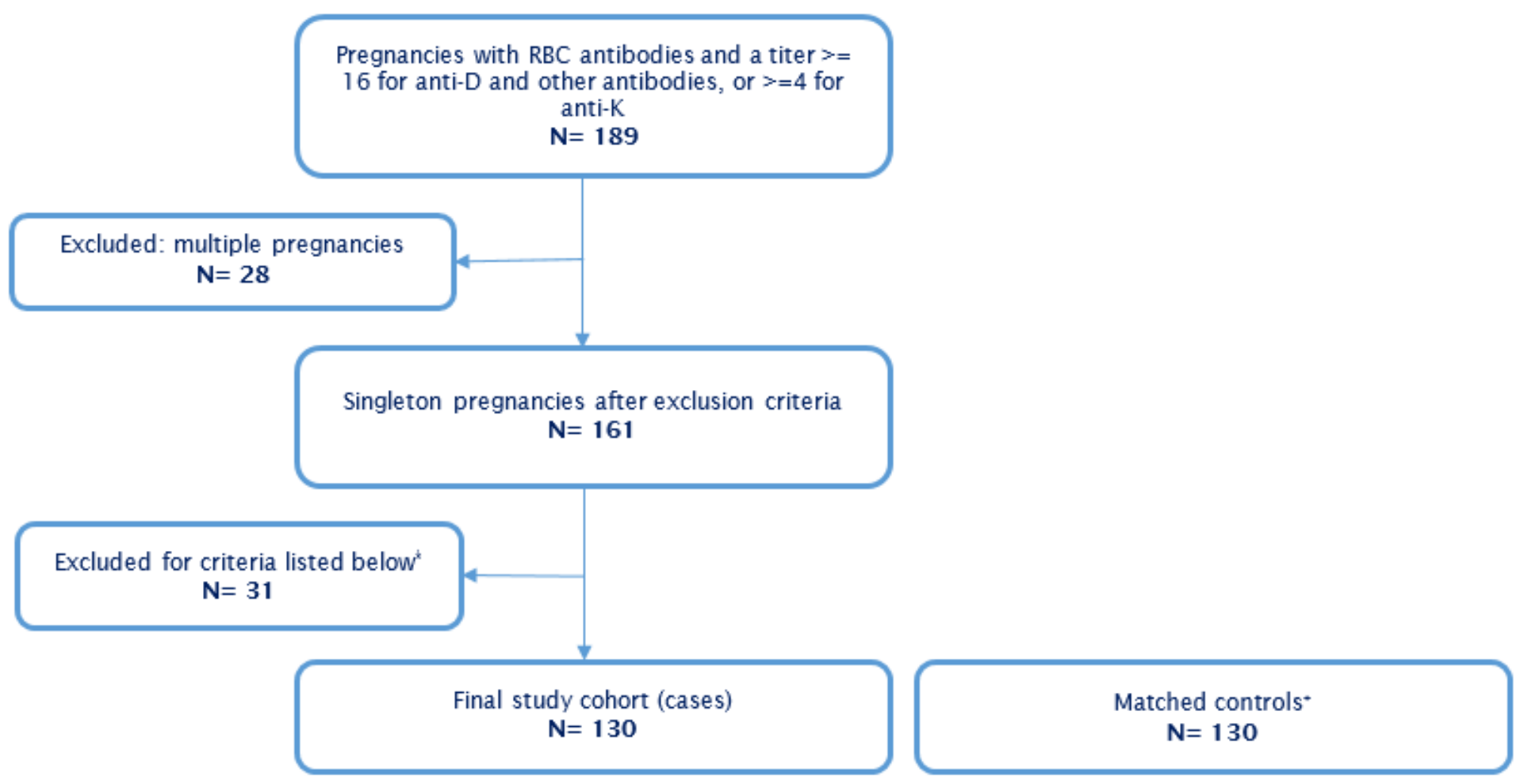

Figure 1

Flowchart of patient inclusion * Maternal age $<18$ years; RBC antibody titers below the threshold; Other antibodies not possibly affecting the offspring; Non-invasive maternal blood testing results indicating an antigen negative fetus; Birth of an antigen-negative child; Unknown pregnancy outcome; Multiple pregnancies; Placenta previa; Maternal pre-existing bleeding disorders: thalassemia, thrombophilia, factor V Leiden, protein S deficiency; Current antithrombotic therapy +Controls without RBC antibodies, matched 1:1 to cases for maternal age and BMl; same exclusion criteria as for cases applied, except for $A B$ and antigen-status of the fetus and newborn

\section{Supplementary Files}

This is a list of supplementary files associated with this preprint. Click to download.

- SupplementalTable.docx 